\title{
Surfactant Protein B Suppresses Lung Cancer Progression by Inhibiting Secretory Phospholipase A2 Activity and Arachidonic Acid Production
}

\author{
Sungmin Lee ${ }^{\mathrm{a}}$ Daehoon Kim ${ }^{\mathrm{a}}$ JiHoon Kang ${ }^{\mathrm{a}}$ EunGi Kim ${ }^{\mathrm{a}}$ Wanyeon Kim ${ }^{\mathrm{b}}$ \\ HyeSook Younc BuHyun Youn a,d
}

aDepartment of Integrated Biological Science, Pusan National University, 'Integrative Graduate Program of Ship and Offshore Plant Technology for Ocean Energy Resource, Pusan National University, Busan, 'Department of Integrative Bioscience and Biotechnology, Sejong University, Seoul, dDepartment of Biological Sciences, Pusan National University, Busan, Republic of Korea

\section{Key Words}

Surfactant protein B - Phospholipase A2 - Arachidonic acid • Lung cancer • Epithelialmesenchymal transition $\cdot$ Radioresistance

\begin{abstract}
Background/Aims: Radiotherapy is applied to patients with inoperable cancer types including advanced stage non-small cell lung cancer (NSCLC) and radioresistance functions as a critical obstacle in radiotherapy. This study was aimed to investigate the mechanism of radioresistance regulated by surfactant protein B (SP-B). Methods: To investigate the role of SP-B in radioresistance, $\triangle$ SFTPB A549 cell line was established and SP-B expression was analyzed. In response to ionizing radiation (IR), the change of SP-B expression was analyzed in A549 and NCI-H441 cell lines. Conditioned media (CM) from NSCLC cells were utilized to evaluate the downstream signaling pathway. The in vivo effects of SP-B were assessed through mouse xenograft model with intratumoral injection of CM. Results: In response to IR, NSCLC cell lines showed decreased SP-B regulated by the TGF- $\beta$ signaling and decreased SP-B stimulated cell survival and epithelial-mesenchymal transition. Treatment with CM from irradiated cells activated $\mathrm{SPLA}_{2^{\prime}}$ enhanced protein kinase C $\delta$-MAPKs signaling pathway, and increased arachidonic acid production. We confirmed the in vivo roles of SP-B through mouse xenograft model. Conclusion: Our results revealed that down-regulation of SP-B was involved in the radiation-induced metastatic conversion of NSCLC and provided evidence that SP-B acted as a suppressor of NSCLC progression.
\end{abstract}




\section{Introduction}

Inoperable cancers such as advanced stage non-small cell lung cancer (NSCLC) require radiotherapy in the absence of more effective targeted therapies [1]. However, radiotherapeutic outcomes are often not fully satisfactory because cell populations that survived after radiotherapy showed radioresistant properties including increased survival and invasiveness [2]. Accordingly, many studies have been conducted to control tumor progression after irradiation and develop potent adjuvants for radiotherapy that improve treatment efficacy [3]. An understanding of molecular events associated with radiationinduced tumor aggressiveness advanced the discovery of drugs that modulate radiationinduced signaling responses and improve the prognosis of patients with NSCLC [4-6]. However, radioresistance is not yet completely overcome and the underlying mechanism is still elusive.

Pulmonary surfactant is a protein-lipid complex that covers alveolar surfaces and prevents collapse of a alveoli [7]. Pulmonary surfactant is composed of four proteins, surfactant protein A, B, C and D (SP-A, B, C, and D). These proteins are abundant in pulmonary alveoli and primarily produced by alveolar epithelial type II cells. SP-A and SP-D are hydrophilic proteins involved in the regulation of innate immune systems in the lung while SP-B and SP-C are hydrophobic proteins which play a role in reducing surface tension in the lung [8, 9]. Functional activity of SP-B is to facilitate lipid adsorption into the interface, which leads to efficient re-spreading of the material during pulmonary expansion upon inhalation and stabilizes multilayer interfacial films during expiration $[10,11]$. According to such functions, SP-B can affect the transfer of membranous phospholipids to target molecules and modulate lipid metabolism in the lung. In cancer studies, however, higher protein expressions of SP-B were reported in the blood of genetically engineered lung cancer mouse model and of lung cancer patients $[12,13]$. These studies suggested the utility of SP-B as a biomarker for lung cancer. However, the detailed role of SP-B in NSCLC progression remains still elusive.

Secretory phospholipase A2 $\left(\mathrm{sPLA}_{2}\right)$ is secreted into the extracellular space, where it catalyzes the hydrolysis of ester bonds at the sn-2 position of phospholipids. In the tumor microenvironment, sPLA ${ }_{2}$ reportedly hydrolyzes surfactant phospholipids and produces eicosanoid lipid mediators that regulate the progression of NSCLC [14]. Previous studies reported that $\mathrm{SPLA}_{2}$ is highly activated in many types of cancer $[15,16]$. SPLA 2 produces several lipid products, including lysophosphatidylcholine and free fatty acids which induce phosphorylation of protein kinase $\mathrm{C} \delta$ and $\varepsilon$ (PKC $\delta$ and $\varepsilon$ ) [17]. Phosphorylated PKC $\delta / \varepsilon$ activates the mitogen-activated protein kinase (MAPK) pathway, leading to activation of cytosolic phospholipase $\mathrm{A} 2 \alpha\left(\mathrm{CPLA}_{2} \alpha\right)$ and this cross-talk between $\mathrm{SPLA}_{2}$ and $\mathrm{cPLA}_{2} \alpha$ is previously reported $[18,19]$. CPLA 2 is the major intracellular form of $\mathrm{PLA}_{2}$ and preferentially hydrolyzes membrane phospholipids to arachidonic acid (AA) via the same mechanism as $\mathrm{SPLA}_{2}$. Once activated, $\mathrm{CPLA}_{2} \alpha$ can produce AAs and other lipid products responsible for activation of $\mathrm{SPLA}_{2}$, which forms a positive feedback loop. The increase in AA by crosstalk between $\mathrm{SPLA}_{2}$ and $\mathrm{CPLA}_{2} \alpha$ plays an important role in promoting cancer progression [20]. In addition, AA can be utilized to produce prostaglandin E2, which induces cell proliferation, immune suppression, angiogenesis and cancer invasion [21]. Therefore, many pharmacological studies covering inhibitors to prevent AA production have been performed in various cancer types [22]. Notably, SP-B was reported to inhibit the activity of sPLA [23]. Although the mechanism is elusive, it can be assumed that SP-B is involved in SPLA ${ }_{2}$-induced tumor progression.

The present study was conducted to overcome post-irradiation recurrence and metastasis mediated by radiation-induced intracellular responses and alterations in the tumor microenvironment in NSCLC cells. To accomplish this, we established $\triangle$ SFTPB NSCLC cell lines and observed alteration of invasiveness of the cells. Additionally, we discovered that radiation down-regulated expression of SP-B through activation of the transforming growth factor- $\beta$ (TGF- $\beta$ ) signaling pathway and decreased SP-B activated the SPLA $_{2}$-PKC $\delta$-MAPK$\mathrm{CPLA}_{2} \alpha$ axis, which promoted cancer cell malignancy. It was observed that administration of 
SP-B improved radiotherapeutic outcomes in an in vivo mouse xenograft model. Overall, the results of this study suggested that SP-B acts as a tumor suppressor in NSCLC.

\section{Materials and Methods}

\section{Reagents and antibodies}

Roswell Park Memorial Institute 1640 medium (RPMI 1640), fetal bovine serum (FBS), penicillin, and streptomycin were acquired from Gibco (Grand Island, NY). Antibodies specific for SP-B, p-PKC $\delta$, PKC $\delta$, and Tubulin were obtained from Santa Cruz Biotechnology (Santa Cruz, CA). Antibodies specific for phosphorylated p-ERK, ERK, p-MEK1/2, and MEK1/2 were purchased from Cell Signaling Technology (Beverly, MA). Recombinant Human TGF- $\beta$ protein was acquired from R\&D Systems (Abingdon, UK).

\section{Cell culture, irradiation and reagent treatment}

A549 and NCI-H441 cell lines were obtained from the American Type Culture Collection (ATCC, Manassas, VA), authenticated, and utilized within 6 months of purchase. Cells were grown in RPMI-1640 medium supplemented with $10 \%$ FBS, $100 \mathrm{U} / \mathrm{mL}$ penicillin, and $100 \mathrm{mg} / \mathrm{mL}$ streptomycin at 37C in $95 \%$ air $/ 5 \% \mathrm{CO}_{2}$. The cells were exposed to a single dose of $\gamma$-rays using a Gamma Cell-40 Exactor (Nordion International, Inc., Ottawa, Ontario, Canada) at a dose rate of $0.81 \mathrm{~Gy} / \mathrm{min}$. Flasks containing the control cells were placed in the irradiation chamber but not exposed to radiation. The cells were treated with TGF- $\beta$ for 6 hours.

\section{Preparation of conditioned media (CM)}

Preparation of CM for recipient cells was performed as previously described [24]. Cells were seeded at a density of $5 \times 10^{5}$ cells $/ \mathrm{mL}$ in $100 \mathrm{~mm}$ culture dishes, incubated for 24 hours, and then exposed to $4 \mathrm{~Gy}$ of radiation or transfected with the SFTPB gene. At 24 hours after treatment, cells were washed with PBS and further incubated in serum-free media without antibiotics for 48 hours. The harvested CM was filtered and concentrated 4-fold using a Centricon-10 concentrator (Millipore, Billerica, MA) at $4^{\circ} \mathrm{C}$, then stored at $-20^{\circ} \mathrm{C}$. Following $\mathrm{CM}$ collection, the number of cells remaining on the dish was counted and the volume of $\mathrm{CM}$ used in each experiment was normalized based on the cell number.

\section{Transient transfection and CRISPR-mediated knock-out of SFTPB}

For transient transfection, $2.5 \times 10^{5}$ cells were plated in $60 \mathrm{~mm}$ dishes and then incubated for 24 hours for stabilization. Next, cells were transiently transfected with $2.5 \mu \mathrm{g}$ of the indicated plasmid using Lipofectamine (Invitrogen, Carlsbad, CA) according to the instructions supplied by the manufacturer.

A novel genome editing technology, clustered regularly interspaced short palindromic repeats (CRISPR), was applied to knock-out the SFTPB gene via guide RNA-directed Cas9 nuclease cleavage. SFTPB CRISPR/Cas9 KO plasmid and SFTPB HDR plasmid were obtained from Santa Cruz Biotechnology (Santa Cruz, CA). For transfection, A549 cell was plated at a density of $2.5 \times 10^{5}$ cells in $60 \mathrm{~mm}$ dishes and then incubated for 24 hours. The cells were subsequently transfected with the indicated plasmids using Lipofectamine (Invitrogen, Carlsbad, CA). After 48 hours, puromycin $(1 \mu \mathrm{g} / \mathrm{ml}$ ) was applied to select stably transduced cells. The selected cells were grown, then harvested, and prepared for measurement of mRNA levels of SFTPB by real-time quantitative Reverse Transcription-PCR (qRT-PCR) and protein levels of proSP-B by Western blot.

Western blot analysis and immunofluorescence (IF)

Samples were prepared for Western blot analysis as previously described [25]. After the desired treatments, cell lysates were prepared using RIPA lysis buffer [50 mM Tris, pH 7.4, $150 \mathrm{mM} \mathrm{NaCl}, 1 \%$ Triton X-100, $25 \mathrm{mM} \mathrm{NaF}, 1 \mathrm{mM}$ DTT, $20 \mathrm{mM}$ EGTA, $1 \mathrm{mM} \mathrm{Na} \mathrm{VO}_{4}, 0.3 \mathrm{mM}$ phenylmethylsulfonyl fluoride (PMSF), and $5 \mathrm{U} / \mathrm{ml}$ aprotinin]. The protein concentration in the lysates was determined using a Bio-Rad protein assay kit. Western blot analysis was performed as previously described [26]. Briefly, protein samples were subjected to SDS-PAGE and transferred to nitrocellulose membrane. The membrane was blocked with $5 \%$ BSA in TBST (10 mM Tris, $100 \mathrm{mM} \mathrm{NaCl}$, and $0.1 \%$ Tween 20) for 1 hour at room temperature and then incubated overnight with adequate primary antibody solution in $4^{\circ} \mathrm{C}$. Then the membrane probed with 


\section{Cellular Physiology Cell Physiol Biochem 2017;42:1684-1700 \begin{tabular}{l|l} 
DOI: 10.1159/000479418 & O 2017 The Author(s). Published by S. Karger AG, Basel \\
www.karger.com/cpb
\end{tabular}}

Lee et al.: SP-B Suppresses Progression of NSCLC

peroxidase-conjugated secondary antibody solution and visualized with ECL detection kit (Abfrontier, Seoul, Republic of Korea).

The experimental procedures for immunofluorescent analysis, have been described in detailed elsewhere [27]. Briefly, cells were grown on a glass slide (Nunc, Naperville, IL) and then subjected to the indicated experimental treatments. The cells were fixed and permeabilized in cold acetone, after which the cells were washed with cold PBS. Following blocking with 1\% BSA in PBS, the cells were incubated overnight with anti-SP-B antibody at $4{ }^{\circ} \mathrm{C}$. Next, the cells were washed three times with cold PBS and probed with DyLight 488-conjugated secondary antibodies (Thermo Scientific, Waltham, MA). After washing and counterstaining with DAPI (Sigma, St Louis, MO), the glass slides were mounted with VECTASHIELD Hard-Set Mounting Medium (Vector Laboratories, Burlingame, CA) and visualized with an Olympus IX71 fluorescence microscope (Olympus Optical Co. Ltd., Tokyo, Japan).

\section{RNA extraction and real-time $q R T-P C R$}

The isolation of RNA, synthesis of cDNA and real-time RT-PCR were performed as previously described [28]. To isolate total RNA from A549 and NCI-H441 cells, Trizol@ reagent (Thermo Fisher Scientific, Grand Island, NY) was utilized and RNA quality was assessed by agarose gel electrophoresis (visual absence of significant 18s and 28s rRNA degradation). Total RNA was subjected to reverse transcription using SuperScript ${ }^{\circ}$ VILO cDNA synthesis kit and master mix (Thermo Fisher Scientific, Grand Island, NY) to obtain cDNA. To perform real-time qRT-PCR, cDNA was applied to MicroAmp ${ }^{\circledR}$ Fast Optical 48-well Reaction Plate (Applied Biosystems, Carlsbad, CA) and mixed with Power SYBR green master mix (Applied Biosystems) and adequate primers. The amplification and detection were performed by StepOne ${ }^{\mathrm{TM}}$ Real-Time PCR system (Applied Biosystems) following manufacturer's instructions. The sequences of used primers were listed below.

Human-SFTPB-F: AATTCCCCATTCCTCTCCCCTAT

Human-SFTPB-R: GATGCCGCCCGCCAC

Human-GAPDH-F: GCTAGGGACGGCCTGAAG

Human-GAPDH-R: GCCCAATACGACCAAATCC

\section{Colony forming assay}

To assess the survival of cancer cells, a colony forming assay was conducted as previously described [29]. Briefly, 2,500 cells were seeded in $60 \mathrm{~mm}$ dishes. After 24 hours, the cells were treated, incubated in the indicated CM and then grown for 14 days. At the end of the incubation period, the cells were fixed with $10 \%$ methanol and $10 \%$ acetic acid and stained with $1 \%$ crystal violet, after which they were visualized with an Olympus IX71 fluorescence microscope.

\section{Three-dimensional culture (3D culture)}

To visualize the invasive morphology of cancer cells, a 3D culture model and immunostaining were utilized as described elsewhere [30]. For the 3D culture, cells were cultured on a chambered glass slide with $100 \%$ growth factor-reduced Matrigel (BD Biosciences, Franklin Lakes, NJ). For IF staining, cells were fixed with $2 \%$ paraformaldehyde for $20 \mathrm{~min}$, permeabilized in $0.5 \%$ Triton X-100 for $10 \mathrm{~min}$ and then stained with primary antibody for 1 hour at room temperature. Subsequently, they were probed with DyLight 488-conjugated secondary antibodies. After counterstaining with Alexa546-phalloidin (Molecular Probes, Eugene, OR) and DAPI, the slides were mounted with VECTASHIELD Hard-Set Mounting Medium. Fluorescent images were visualized with an Olympus IX71 fluorescence microscope.

Wound healing assay

To assess the migration capacity of cancer cells, we conducted a wound healing assay as previously described [31]. NSCLC cells were seeded at a density of $5 \times 10^{5}$ cells $/ \mathrm{mL}$ in $60 \mathrm{~mm}$ culture dishes. Monolayers of cells with $70 \%$ confluency were scratched using a $1000 \mu \mathrm{L}$ pipette tip and then the media was changed into RPMI-1640 medium supplemented with 1\% FBS. The cells were further incubated with fresh medium with adequate treatment. Photomicrographs were then taken at 100× magnification with an Olympus IX71 fluorescence microscope. To statistically analyze the closeness of wound, we utilized Image J software. Measured wound area was converted into pixels and analysis was performed. 


\section{Cellular Physiology Cell Physiol Biochem 2017;42:1684-1700 \begin{tabular}{l|l} 
and Biochemistry Published online:July 25, 2017 & $\begin{array}{l}\text { O 2017 The Author(s). Published by S. Karger AG, Basel } \\
\text { www.karger.com/cpb }\end{array}$ \\
\cline { 2 - 3 }
\end{tabular}}

Lee et al.: SP-B Suppresses Progression of NSCLC

Enzyme-linked immunosorbent assay (ELISA)

The assessment of mature SP-B and AA was conducted as previously described [32]. Briefly, $3 \times 10^{5}$ cells were seeded in $60 \mathrm{~mm}$ plates and then exposed to a specific dose of radiation. After 12 hours, cells were treated with the indicated CM for 24 hours, washed with PBS, and then incubated in RPMI medium containing $1 \mathrm{mg} / \mathrm{mL}$ BSA for 6 hours. To measure mature SP-B, the media was harvested and concentrated by 4-fold and applied to Human SP-B ELISA kit (USCN Life Science Inc., Houston, TX). To assess the amount of AA in media and tumor from mouse xenograft model, the media and tumor lysates were utilized to measure the level of AA using a human AA ELISA kit (Cusabio Biotech, Wuhan, Hubei, China).

\section{Animal care protocol and tumor xenografts in nude mice}

The animal care protocols were approved by the Institutional Animal Care and Use Committee of Pusan National University (Busan, Republic of Korea), and all experiments were performed in accordance with the provisions of the NIH Guide for the Care and Use of Laboratory Animals. The mice were housed individually or in groups of up to five in sterile cages. They were maintained in animal care facilities in a temperature-regulated room $\left(23 \pm 1^{\circ} \mathrm{C}\right)$ with a 12 hours light/dark cycle and quarantined for 1 week prior to the study. Additionally, all animals were fed water and chow ad libitum. Tumor xenografts in nude mice were conducted as previously described [25]. Briefly, six-week-old male BALB/c athymic nude mice (Central Lab Animals Inc., Seoul, South Korea, $\mathrm{n}=3$ per group) were injected in the flank with $2 \times 10^{6}$ A549 cells, after which tumors were allowed to develop. Upon identification of a palpable tumor (minimum volume of $200 \mathrm{~mm}^{3}$ ), CM was injected into the tumors using insulin syringes every 4 days. Mice in the non-CM treated groups were treated with normal media as a control. The animals were also irradiated with 10 Gy once a week for 4 weeks. Tumor length (L) and width (l) were measured with a caliper and tumor volumes were calculated using the formula $\left(\mathrm{L} \times \mathrm{l}^{2}\right) / 2$ every 5 days [33]. At the end of the treatment period, animals euthanized and the tumors were used for biochemical studies.

\section{Statistical analysis}

All numerical data are presented as the means \pm SEM and sample sizes are calculated to allow significance to be reached. Experimental results were analyzed by one-way analysis of variance (ANOVA) followed by Tukey's honestly significant difference test, or by unpaired student's t-test. Prism 5 software (GraphPad Software, San Diego, CA) was used to conduct statistical analysis, and statistical significance was accepted at $\mathrm{p}<0.05$.

\section{Results}

Knock-out of SP-B enhances cell survival and migration in NSCLC

It has been reported that higher levels of SP-B were detected in the blood of mice and patients with lung cancers $[12,13]$. In transcriptomic analysis studies, the expression level of SP-B was observed to vary $[34,35]$. In the same context with the controversy, we could find down-regulation or up-regulation of SFTPB expression in lung adenocarcinoma compared to normal lung tissue in Oncomine database (http://oncomine.org, Fig. 1A). Based on the results of the previous study showing that the expression of SP-B was related to the degree of lung cancer progression, we investigated the role of SP-B in promoting malignancy of NSCLC [36]. To identify the contribution of SP-B in the progression of NSCLC, we established A549 with depleted SFTPB expression. The CRISPR system was utilized to delete SFTPB gene and the designed plasmids are depicted in Fig. 1B. The results of real-time qRT-PCR and Western blot analysis revealed a significant reduction of SFTPB and SP-B in $\triangle$ SFTPB A549 cells (Fig. 1B). To investigate the role of SP-B in tumor progression, we assessed the migration capacity of $\triangle$ SFTPB A549 cells by a wound healing assay. Ionizing radiation (IR) was utilized as an inducer of EMT and migration of NSCLC according to a previous study [37]. The results showed that both irradiated and $\triangle$ SFTPB A549 cells had more narrow gaps at 36 hours after seeding (Fig. 1C). To assess morphological alterations in response to IR and depletion of SFTPB in A549 cells, the 3D culture model with Tubulin staining (green) was used as previously described [38]. As shown in Fig. 1D, both irradiated and $\triangle$ SFTPB A549 


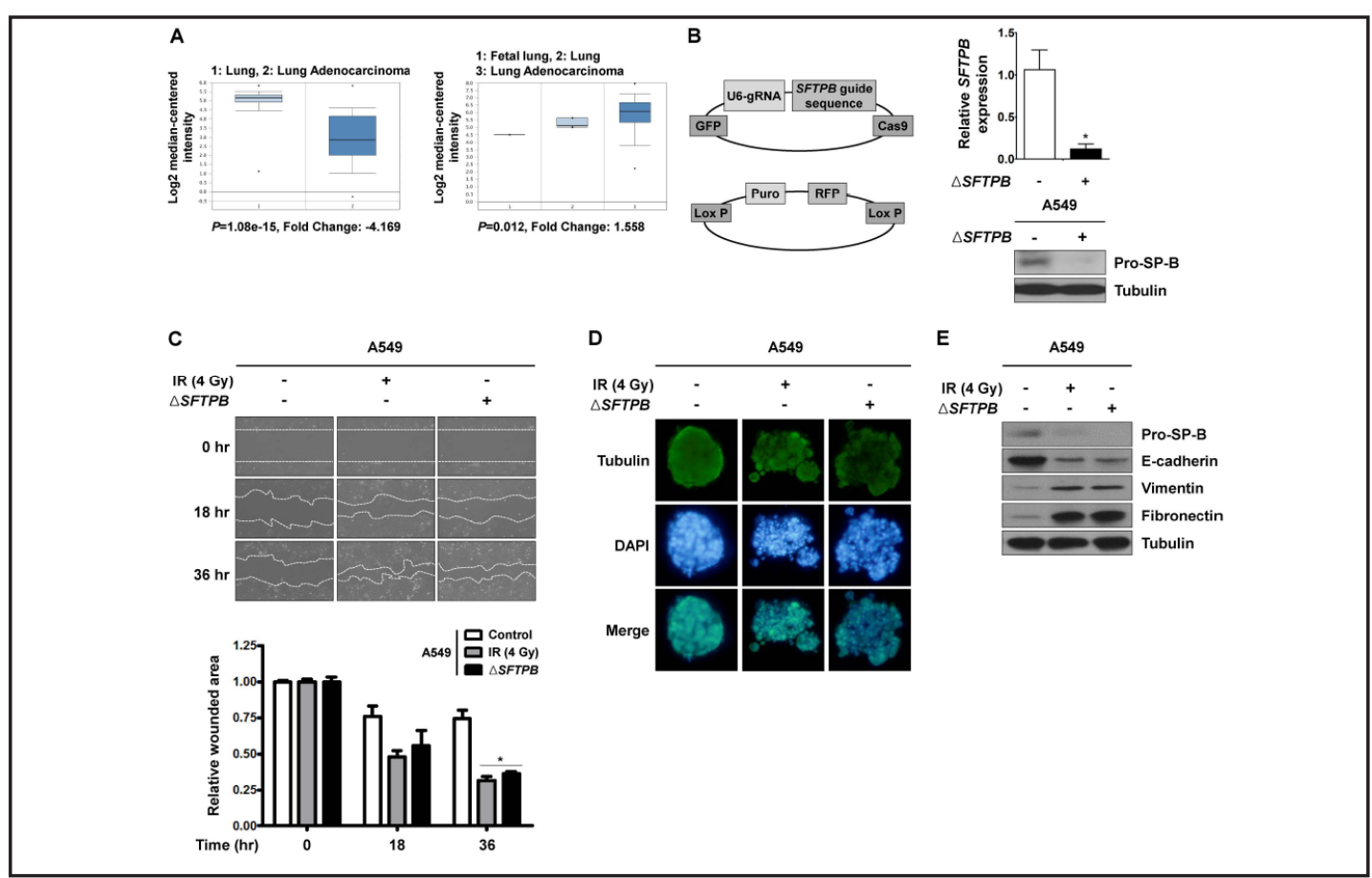

Fig. 1. Deletion of SP-B by the CRISPR system promotes cancer cell progression. (A) Expression of the SFTPB gene in lung cancer and normal lung was evaluated using the Oncomine database (http://www.oncomine. org) [34]; $p=1.08 \mathrm{e}-15$, Fold change $=-4.169$, [35]; $p=0.012$, Fold change $=1.558$. (B) The composition of CRISPR plasmid was depicted and selective knockdown of SFTPB by the CRISPR system was verified by Western blot analysis and real-time qRT-PCR. ${ }^{*}, p=0.0178$ compared to control (student's $t$-test). (C) The migration capacity of $\triangle S F T P B$ A5 49 cells was assessed by a wound healing assay. Following irradiation treatment, cells were wounded and incubated for 36 hours. The numerical analysis was depicted below. *, $p<0.05$ compared to control cells. $P=0.1084$ for 18 hours and $p=0.0004$ for 36 hours (one-way analysis of variance (ANOVA)). (D) Morphological changes in $\triangle S F T P B$ A549 cells were monitored with a 3D culture model. Cells were grown on Matrigel and fixed, after which they were immunostained for Tubulin (green) and nuclei (blue). (E) The changes in expression of EMT marker proteins upon radiation exposure or knockout of SFTPB were analyzed by Western blot analysis.

cells showed star-like and mesenchymal morphology in contrast to the cobblestone-like morphology found in control A549 cells. These alterations related with invasiveness were confirmed through analysis for expression of EMT markers. We observed that both irradiated A549 and $\triangle$ SFTPB A549 cells showed lower E-cadherin expression and higher Vimentin and Fibronectin expression than control cells (Fig. 1E). Overall, these results demonstrated that decreased expression of SP-B could induce cancer progression by enhancing the invasiveness of NSCLC and that SP-B functions as a tumor suppressor.

\section{Radiation exposure decreases SP-B $m$ RNA and protein levels}

Although radiation exposure induces the death of the cancer cells, it has also been suggested to enhance tumor progression of survived cells through modification of intracellular and extracellular characteristics of survived cells. $[39,40]$. In this context, we hypothesized that radiation modulates SP-B expression and that this change is involved in tumor progression in response to radiation. To confirm an involvement of radiation in SP-B expression, we investigated the alteration of SP-B expression upon irradiation. First, we assessed SFTPB mRNA expression in various types of NSCLC cells and observed that radiation generally decreased SFTPB mRNA level in a dose-dependent manner (Fig. 2A). Among these, A549 and NCI-H441 cells were originated from alveolar epithelial type II cells reportedly producing abundant SP-B and were chosen for further experiments [41]. We found that the level of SFTPB mRNA was significantly decreased in 2 and 4 Gy of irradiation 


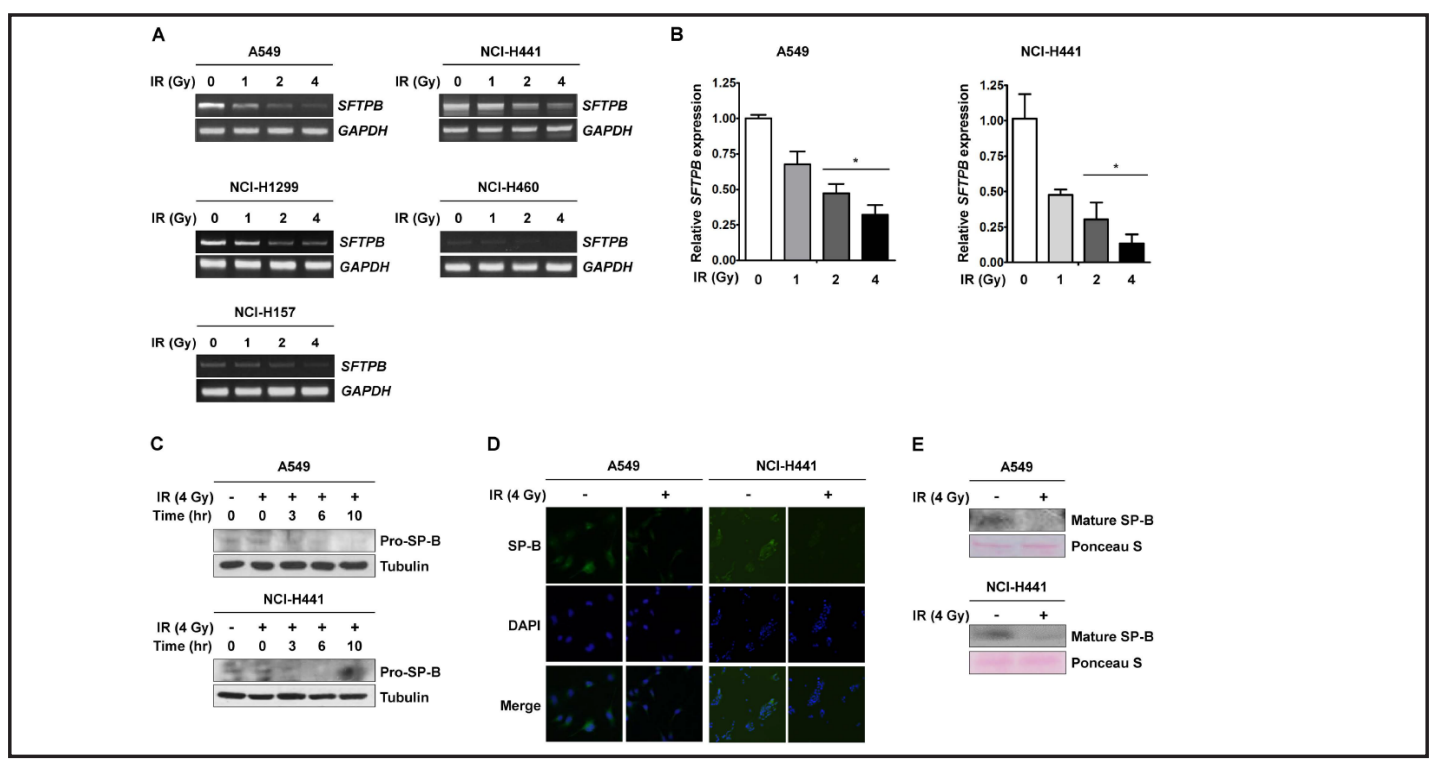

Fig. 2. Radiation decrease SP-B expression and secretion. (A) The radiation-induced alteration of mRNA levels of SFTPB in A549, NCI-H441, NCI-H1299, NCI-H460 and NCI-H157 cells were measured by semi-quantitative qRT-PCR. The cells were harvested 3 hours after 0,1, 2 or 4 Gy of irradiation. (B) The effects of radiation on the mRNA levels of SFTPB in A549, NCI-H441 by real-time qRT-PCR. The cells were harvested 3 hours after $0,1,2$ or 4 Gy of irradiation. ${ }^{*}, p<0.05$ compared to control cells. $P=0.0042$ for A549 and $p=0.0067$ for NCI-H441 (one-way ANOVA) (C) Radiation-induced SP-B protein expression in A549 and NCI-H441 cells was detected by Western blot analysis. The cells were harvested 0, 3, 6, or 12 hours after irradiation. (D) Radiation-induced SP-B expression was visualized by IF. The cells were immunostained 3 hours after irradiation. SP-B or nuclei was immunostained in green or blue, respectively. (E) Decreased mature SP-B was detected by Western blot analysis. Media was harvested 24 hours after irradiation.

in both A549 and NCI-H441 cells (Fig. 2B). In Western blot analysis, decreased pro-SP-B protein levels also decreased in response to radiation in a time-dependent manner in both A549 and NCI-H441 cells (Fig. 2C). The effects of radiation exposure on SP-B expression were confirmed by immunocytochemistry (Fig. 2D). It has been reported that $43 \mathrm{kDa}$ proSP-B can be cleaved into $9 \mathrm{kDa}$ mature SP-B by cathepsin $\mathrm{H}$ [42]. Therefore, we measured the mature SP-B in media of NSCLC cells by ELISA and Western blot analysis. The results revealed that the levels of mature SP-B also decreased in response to irradiation in both A549 and NCI-H441 cells (Fig. 2E).

\section{TGF- $\beta$ signaling pathway is involved in regulation of SFTPB expression}

As the expression of cathepsin $\mathrm{H}$, mediating cleavage of pro-SP-B, is independent of IR exposure, we attribute the radiation-induced decrease of SP-B to transcriptional regulation [43]. The known transcription factors of SFTPB were thyroid transcription factor-1 (TTF-1) and forkhead box protein A1 (FOXA1), which commonly lose their transcriptional activity in response to activation of Smad3 [44]. Smad3 was the downstream effector of the TGF- $\beta$ signaling pathway and radiation was widely suggested to be an inducer of TGF- $\beta$ expression and an activator of TGF- $\beta$ signaling [45]. In this study, we validated that activation of the TGF- $\beta$ signaling pathway by treatment of TGF- $\beta$ ligand resulted in suppression of both mRNA and protein expression of SP-B in A549 and NCI-H441 cells (Fig. 3A and B). Additionally, radiation exposure activated the TGF- $\beta$ signaling pathway through phosphorylation of Smad3 and reduced pro-SP-B expression (Fig. 3C). To verify the involvement of Smad3 in regulation of SFTPB expression, we conducted experiments utilizing SMAD3 knock-down in A549 and NCI-H441 cells. As shown in Fig. 3D, we observed that radiation exposure did not suppress pro-SP-B expression without SMAD3 expression in both cell lines. Moreover, treatment with TGF- $\beta$ ligand also failed to down-regulate pro-SP-B expression in SMAD3 


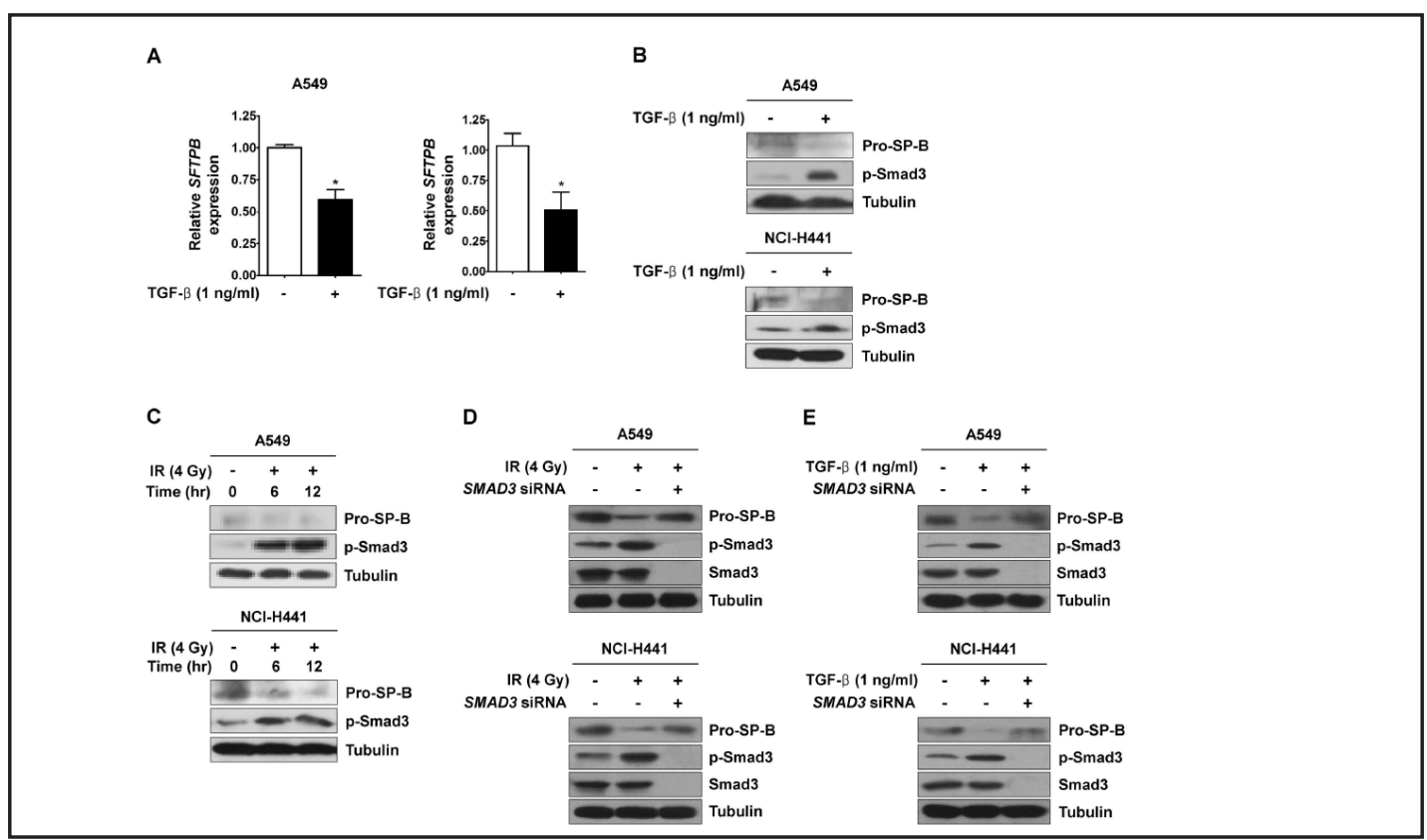

Fig. 3. The TGF- $\beta$ signaling pathway is involved in radiation-induced SFTPB suppression (A) The effects of TGF- $\beta$ treatment on the mRNA levels of SFTPB in A549 and NCI-H441 cells were measured by real-time qRTPCR. Cells were harvested 3 hours after treatment of TGF- $\beta$ at $1 \mathrm{ng} / \mathrm{mL} .{ }^{*}, p=0.0289$ for A549 and $p=0.042$ for NCI-H441 compared to control cells (student's $t$-test). (B) The effects of TGF- $\beta$ treatment on protein levels of pro-SP-B and p-Smad3 in A549 and NCI-H441 cells were detected by Western blot analysis. (C) The effects of radiation on protein levels of pro-SP-B and p-Smad3 in A549 and NCI-H441 cells were detected by Western blot analysis. (D) The changes of pro-SP-B expression and Smad3 phosphorylation upon radiation exposure was measured by Western blot analysis. (E) The changes of pro-SP-B expression and Smad3 phosphorylation upon treatment with TGF- $\beta$ ligand was measured by Western blot analysis.

knock-down condition (Fig. 3E). Taken together, these findings indicated that decreased SP-B expression in response to radiation is mediated by an activation of the TGF- $\beta$-Smad3 signaling pathway.

\section{$S P-B$ is involved in regulation of SPLA2-PKC $-M A P K s-C P L A 2 \alpha$ pathway}

To gain further insight into the precise mechanism by which reduced SP-B is involved in cancer progression, we attempted to identify molecular target of SP-B. Pro-SP-B needs cleavage to be functionally activated and secreted to extracellular environment [46]. According to previous studies, SP-B suppressed SPLA activity and SPLA transduced signaling through the $\mathrm{SPLA}_{2}$-PKC-ERK-CPLA $\alpha$ pathway $[18,23]$. To confirm the inhibitory role of secreted mature SP-B on SPLA 2 signaling pathway, we utilized CM. CM A derived from non-treated NSCLC cells contained modest, CM B derived from irradiated NSCLC cells contained lowest, and CM C derived from SFTPB-transfected NSCLC cells contained highest levels of SP-B. The content of mature SP-B in each CM was measured by ELISA (Fig. 4A). It was observed that radiation exposure reduced the level of mature SP-B into one-fifth and SFTPB overexpression increased the level of mature SP-B by 5 -fold. As shown in Fig. 4B, A549 and NCI-H441 cells were exposed to each CM for 12 hours, and phosphorylation of $\mathrm{PKC} \delta$ was found to decrease in response to treatment with CM A, but to increase in response to treatment with CM B. In the irradiated condition, high activation of PKC $\delta$ was observed and the same effects of CMs on PKC $\delta$ phosphorylation were observed in irradiated A549 and NCI-H441 cells. Next, to determine the involvement of SP-B in suppression of PKC $\delta$, we measured PKC $\delta$ phosphorylation by treatment with CM C. Radiation-induced phosphorylation of PKC $\delta$ was slightly decreased by treatment with CM A and further decreased by treatment with CM C (Fig. 4B). We next investigated the effects of SP-B in activation of MAPKs pathway 


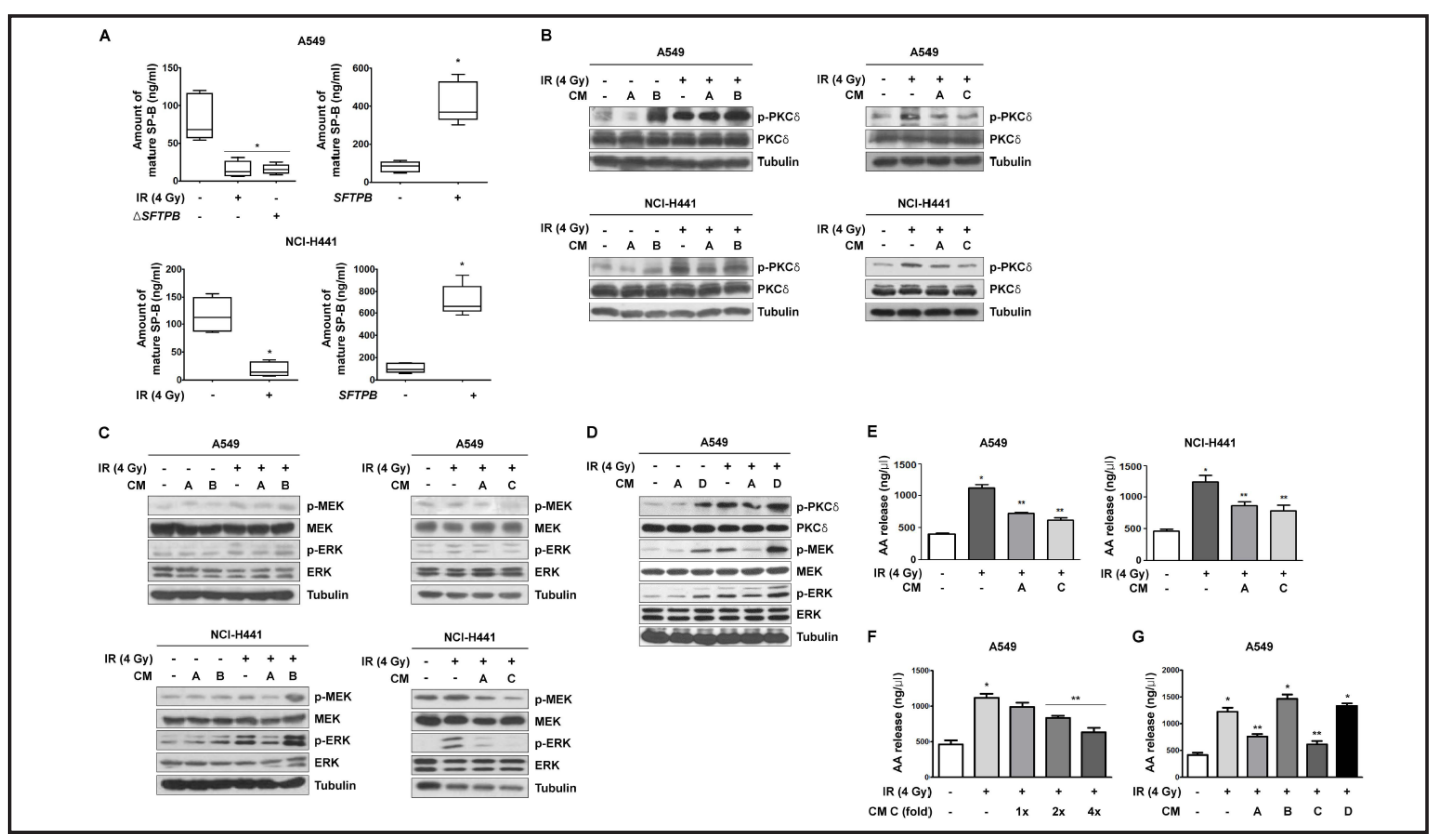

Fig. 4. SP-B inhibits activity of the $\mathrm{SPLA}_{2}$ and PKC $\delta$-MAPKs-cPLA ${ }_{2} \alpha$ signaling pathway. (A) The levels of mature SP-B protein were detected by ELISA. Media was harvested 48 hours after irradiation, SFTPB overexpression, or $\triangle S F T P B .^{*}, p<0.05$ compared to control cells. $P=0.0017$ for IR vs. control cells, $p=0.0002$ for $S F T P B$, and $p<0.0001$ for $\triangle S F T P B$ vs. control cells of A549. $P=0.0001$ for IR vs. control cells and $p=0.0017$ for SFTPB vs. control cells of NCI-H441 (student's $t$-test) (B) The effects of CM from irradiated cells or SFTPB overexpressing cells on $\mathrm{PKC} \delta$ activation were analyzed by Western blot analysis. CM was treated 12 hours after irradiation. (C) The effects of CM from irradiated cells or SFTPB overexpressing cells on activation of the MAPK signaling were detected by Western blot analysis. (D) The effects of CM from $\triangle S F T P B$ cells on PKC $\delta$-MAPK activation were analyzed by Western blot analysis. (E) The effects of CM with enriched mature SP-B on the alterations of AA production were measured by ELISA. After treatment with each CM, media was changed to fresh serum-free media and then was harvested 6 hours later for measurement. *, $p<0.05$ compared to control cells; **, $p<0.05$ compared with irradiated cells. $P<0.0001$ for A549 and NCI-H441 (one-way ANOVA). (E) The effects of CM C with different concentration on the alteration of AA production were measured by ELISA. Each CM was harvested, differently concentrated, and treated to irradiated cells. *, $p<0.05$ compared to control cells; ${ }^{* *}, p<0.05$ compared with irradiated cells. $P<0.0001$ (one-way ANOVA). (F) The effects of CM on the alterations of AA production were measured by ELISA. *, $p<0.05$ compared to control cells; ${ }^{* *}, p<0.05$ compared with irradiated cells. $P<0.0001$ (one-way ANOVA).

downstream of PKC $\delta$. The increased phosphorylation of MEK1/2 and ERK upon irradiation were reduced by treatment with CM A and increased by treatment with CM B (Fig. 4C). These effects were more significantly shown in irradiated cells compared to non-irradiated cells. Moreover, treatment with CM C resulted in a further decrease of radiation-induced MEK1/2 and ERK phosphorylation compared to treatment with CM A in the subsequent experiment. Additionally, we utilized CM D, derived from $\triangle$ SFTPB A549 cells, and treatment with CM D enhanced activation of PKC $\delta$, MEK1/2, and ERK in recipient cells along with that of CM B (Fig. 4D). These findings indicated that SP-B inhibits the $\mathrm{SPLA}_{2}$ activity and subsequently the PKC $\delta$ MAPKs and radiation-induced suppression of SP-B resulted in activation of PKC $\delta$-MAPKs pathway in NSCLC cells. As described above, $\mathrm{CPLA}_{2} \alpha$ is a downstream effector of sPLA $-\mathrm{PKC} \delta$ MAPKs signaling and it is known that active $\mathrm{CPLA}_{2} \alpha$ produced $\mathrm{AA}$ and lysophospholipids from phospholipids [47]. To verify the involvement of SP-B in the activity of $\mathrm{CPLA}_{2} \alpha$, we measured the levels of extracellular AA. As shown in Fig. 4E, radiation exposure increased the secretion of AA from NSCLC cells, which was alleviated by treatment with CM A and C. We also observed that the effect of CM C was enhanced dependent on the concentration and even 2 -fold concentration could induce significant effect on AA release from A549 cells (Fig. 4F). 


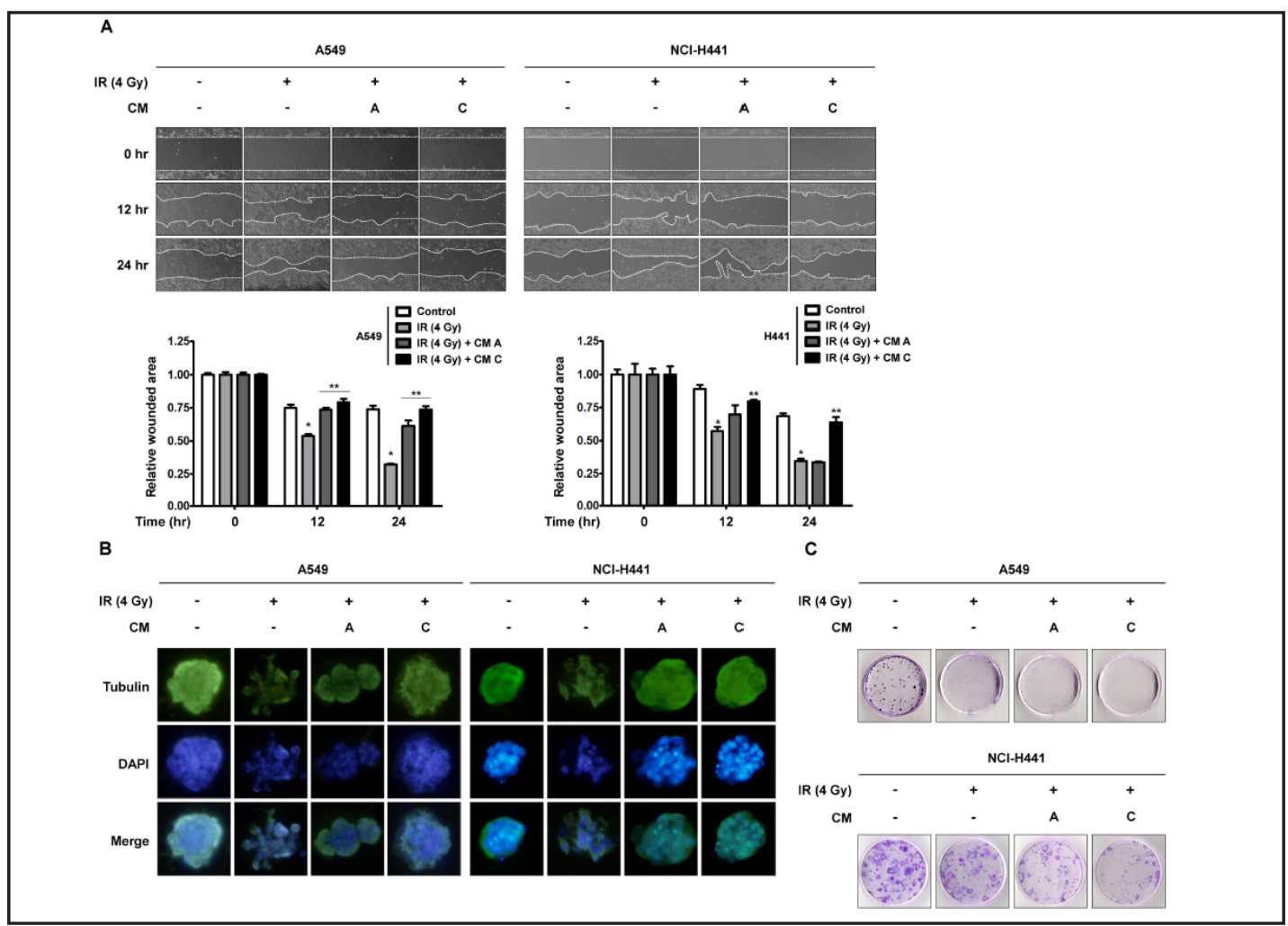

Fig. 5. Radiation-induced NSCLC progressions are regulated by mature SP-B. (A) The effects of CM with enriched mature SP-B on inhibition of the migration capacity were assessed by a wound healing assay. Following treatment with radiation and CM, cells were wounded and incubated for 24 hours. The numerical analysis was depicted below. ${ }^{*}, p<0.05$ compared to control cells; ${ }^{* *}, p<0.05$ compared to irradiated cells. $P<0.0001$ for 12 and 24 hours of A549. $P=0.0033$ for 12 hours and $p<0.0001$ for 24 hours of NCI-H441 (one-way ANOVA). (B) The effects of CM with enriched mature SP-B on morphological changes were visualized using a 3D culture model. Tubulin and nuclei were immunostained in green or blue, respectively. (C) The effects of CM with enriched mature SP-B on inhibition of survival to radiation-induced cell death were assessed by a colony forming assay.

However, the administration of CM B or CM D could not prevent the release of AA induced by irradiation (Fig. 4G). The results showed that the SP-B was especially involved in regulation of AA production. Taken together, we found that radiation-induced tumor progression is mediated by suppression of SP-B, which enhances the SPLA $_{2}$-PKC $\delta$-MAPKs-cPLA $2 \alpha$ pathway and production of AA.

\section{$S P-B$ functions as a suppressor of NSCLC progression}

We investigated $\mathrm{SPLA}_{2}$ was a functional target of SP-B and AA was the key molecule downstream of the $\mathrm{SPLA}_{2}$ pathway. Several lines of evidence have shown that high levels of AA are positively correlated with tumor progression, including EMT induction and metastasis $[48,49]$. According to these findings, we investigated the involvement of CMs in induction of tumor progressive changes. In a wound healing assay, radiation-induced invasiveness of A549 was significantly suppressed by administration of CM A and C (Fig. 5A). Instead, it was observed that only CM C caused significant effects on invasiveness in NCI-H441 cells. In the 3D culture model, we found that the NSCLC cells treated with CM A and C also showed less mesenchymal morphology (Fig. 5B). These results indicated that high amount of SP-B suppresses radiation-induced invasiveness and EMT. Because increased survival is the commonly suggested radioresistance after radiotherapy, we assessed alterations of survival capacity of NSCLC cells following radiation exposure and CM treatment [24]. According to 


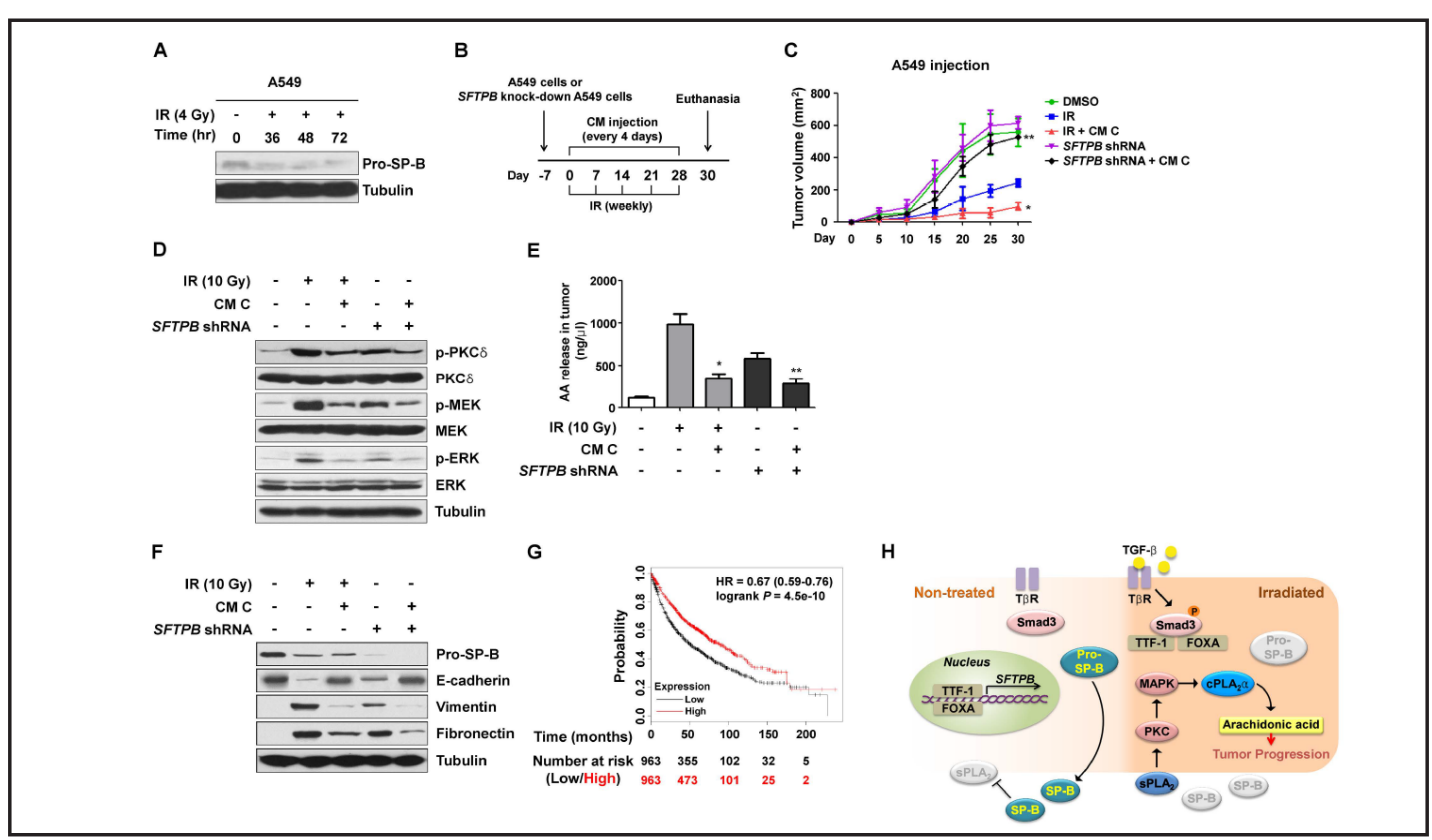

Fig 6. SP-B inhibits tumor growth and EMT in a mouse xenograft model. (A) The duration of radiation-induced SP-B suppression was examined by Western blot analysis. (B) A schematic summary of the experimental procedure to determine the effects of SP-B on in vivo tumor growth and EMT in a mouse xenograft model. (C) The effects of mature SP-B and radiation on tumor growth in mouse xenograft models were measured. ${ }^{*}, p<0.05$ compared to irradiated group; ${ }^{* *}, p<0.05$ compared to SFTPB shRNA group. $P=0.0004$ for IR vs. IR + CM C and $p=0.0172$ for SFTPB shRNA vs. SFTPB shRNA + CM C (student's $t$-test) (D) The in vivo effects of CM with enriched mature SP-B irradiation on activation of PKC $\delta$-MAPKs signaling pathway were analyzed by Western blot analysis. (E) The in vivo effects of CM with enriched mature SP-B irradiation on production of AA in tumor were measured by ELISA. *, $p<0.05$ compared to irradiated group; **, $p<0.05$ compared to SFTPB shRNA group. $P<0.0001$ (one-way ANOVA). (F) The in vivo effects of CM with enriched mature SP-B irradiation on EMT were measured by Western blot analysis. (G) The prognostic value of SFTPB expression was analyzed by a Kaplan-Meier survival database (http://kmplot.com). The desired Affymetrix ID is valid: 37004_at (SFTPB). Survival curves are plotted for all patients $(n=1436)$. (H) A graphical summary of the mechanism of radiation-induced SP-B suppression and tumor progression.

the colony forming assay, survival of A549 and NCI-H441 reduced in the irradiated cells and treatment with CM A and C sensitized both cells to radiation-induced cell death (Fig. 5C). These findings indicated that SP-B secreted from the NSCLC cells regulated tumor malignancy and resistance to the therapies.

$S P-B$ decreased tumor growth and radiation-induced EMT in a mouse xenograft model

Next, we conducted xenograft experiments to investigate the role of SP-B on in vivo tumor growth and EMT. Prior to the xenograft experiment, we confirmed the duration of radiationinduced SP-B suppression. We observed that decreased SFTPB expression in response to a radiation exposure was prolonged by up to 72 hours in A549 cells (Fig. 6A). Based on this result, we designed to inject CM every 4 days to keep the effect of CM on tumor and detailed schedules are depicted in Fig. 6B. Through the mouse xenograft model, we observed that tumors in mice treated with both CM C and radiation showed significantly less growth on day 30 compared to those of tumors treated with radiation alone, which is consistent with the in vitro data (Fig. 6C). Additionally, tumor volume of SFTPB knock-down cells treated with CM C was decreased than SFTPB knock-down cells. However, tumor volume of SP-B knock-down cells did not show significant differences compared to that of non-treated cells. It can be inferred that SFTPB knock-down did not affect tumorigenic capacity of NSCLC cells. Consistent with our in vitro results, phosphorylation of PKC $\delta, M E K-1 / 2$ and ERK was 


\begin{tabular}{|c|c|c|}
\hline Cellular Physiology & Cell Physiol Biochem 2017; & 2::1684-1700 \\
\hline and Biochemistrv & $\begin{array}{l}\text { DOI: 10.1159/000479418 } \\
\text { Published online: July 25, } 2017\end{array}$ & $\begin{array}{l}\text { O } 2017 \text { The Author(s). Published by S. Karger AG, Basel } \\
\text { www.karger.com/cpb }\end{array}$ \\
\hline
\end{tabular}

Table 1. Multivariate analysis of survival of lung cancer patients

\begin{tabular}{lccc}
\hline Variables & $P$-value & Hazard Ratio & 95\% Confidence Interval \\
\hline SFTPB expression & 0.0471 & 0.72 & $(0.52-1)$ \\
NKX2-1 expression & 0.6102 & 1.09 & $(0.78-1.53)$ \\
Histology & 0.0676 & 1.35 & $(0.98-1.85)$ \\
Stage & $<0.0001$ & 1.74 & $(1.41-2.14)$ \\
Gender & 0.1046 & 1.3 & $(0.95-1.79)$ \\
Smoking history & 0.1498 & 0.71 & $(0.44-1.13)$ \\
\hline
\end{tabular}

decreased in the extracted tumor lysates obtained from mice treated with $\mathrm{CM} \mathrm{C}$ compared to treatment with radiation alone or SFTPB shRNA (Fig. 6D). The levels of AA secretion also increased in response to treatment with radiation or SFTPB shRNA but decreased in response to treatment with $\mathrm{CM} \mathrm{C}$ in the extracted tumor lysates (Fig. 6E). Furthermore, the in vivo involvement of SP-B in EMT was confirmed by expression of EMT marker in tumor lysates. We observed that E-cadherin expression decreased and Vimentin and Fibronectin expression increased in tumor lysates from mice treated with radiation alone or SFTPB shRNA. Additionally, treatment with CM C increased E-cadherin expression and decreased Vimentin and Fibronectin expression compared to treatment with radiation alone or SFTPB shRNA (Fig. 6F). To confirm the SP-B expression is associated with prognosis of lung cancer, we utilized Kaplan-Meier survival database (http://kmplot.com) [50]. We could find that the survival probability of lung cancer patients with lower expression of SFTPB was significantly lower (Fig. 6G). In the previous study, it was reported that the expression of NKX2-1, the gene name of the TTF-1 which regulates SFTPB expression, was suggested to be negatively related to the survival of lung cancer patients [51]. To verify that SFTPB expression was more critically involved in lung cancer patient survival than that of NKX2-1, we performed multivariate analysis provided by Kaplan-Meier survival database. Moreover, we conducted the analysis utilizing clinical factors including histology, stage, gender, and smoking history. As a result, we found that SFTPB expression showed significant p-value (0.0471) in analysis and its hazard ratio was 0.72 (can be inverted into 1.39) (Table 1). Instead, NKX2-1 expression showed non-significant p-value (0.6102) and hazard ratio (1.09). Among the clinical factors, histology and stage showed significant hazard in patient survival, but gender and smoking history did not. Taken together, we concluded that SP-B functions as a suppressor in tumor progression of NSCLC in vivo and the low expression of SFTPB can be suggested as the strong prognostic marker for the lung cancer patients.

\section{Discussion}

As mentioned above, the expression of SP-B varied in previous proteomic and microarray studies $[12,13,34,35]$. Therefore, we conducted this study to explain these variations and understand the precise involvement of SP-B in tumor progression. As summarized in Fig. $6 \mathrm{H}$, we found that the radiation-induced activation of the TGF- $\beta$ signaling pathway resulted in suppression of SP-B expression. Moreover, reduced mature SP-B resulted in activation of the $\mathrm{SPLA}_{2}-\mathrm{PKC} \delta$-MAPKs-cPLA $\alpha$ pathway and production of tumor progressive AA as a final effector. These findings indicated that SP-B plays a tumor suppressive role in NSCLC and that radiation-induced SP-B suppression promotes the tumor growth and invasiveness responsible for the occurrence of radioresistance.

Secretory proteins that have tumor suppressive functions and direct treatment of these proteins have been introduced as a promising strategy for anti-tumor therapy [52]. For example, melanoma differentiation associated gene-7/Interleukin-24 (mda-7/IL-24) has been suggested to have tumor suppressive activities in all types of cancers through induction of apoptosis in cancer cells [53]. The successful anti-tumor effects of mda-7/IL24 administration were approved in a phase I/II clinical trial without normal tissue injury 
$[54,55]$. Follistatin-like (FSTL) proteins were also suggested as tumor suppressive secretory proteins. FSTL1 was found to induce apoptosis through up-regulation and activation of pro-apoptotic proteins in ovarian cancer [56]. Treatment and overexpression of FSTL5 have been reported to inhibit cancer survival via suppression of Wnt/ $\beta$-catenin signaling in hepatocellular carcinoma [57]. Moreover, a recent study described the tumor suppressive role of secretory SP-D as a competitive inhibitor for EGF-EGFR binding [58]. Taken together, these studies indicated that secretory protein has a potential to cure various types of cancer and that SP-B can be suggested for treatment of lung cancers.

One of the challenges reducing the efficacy of radiotherapy is the occurrence of radiationinduced normal tissue injury. Development of pulmonary fibrosis has been reported as a severe side effect following thoracic radiotherapy to treat lung and breast cancer [59]. The association of respiratory distress syndrome (RDS) with the induction of pulmonary fibrosis has also been reported and even the approach to cure both RDS and fibrosis through treatment with single adjuvant was issued in current study [60,61]. RDS is caused by loss of pulmonary surfactant and the deficiency of SP-B and SP-C was observed in acute and chronic RDS (ARDS and CRDS) patients [62]. Deficiency of SP-B induced lethality of neonatal mice and pulmonary failure in adult mice, which suggested a critical role of SP-B in alveolar homeostasis [63]. In a previous report, lower expression of SP-A and SP-D was observed in patients that received thoracic radiotherapy, while the alteration of SP-B expression in patients treated with radiotherapy has not been reported [64]. According to our results, it was found that irradiation-induced reduction of SP-B expression might be common in lung cells and mediated by the TGF- $\beta$ signaling pathway (Fig. 3). Many current studies described that TGF- $\beta$ is a key mediator of fibrosis in various types of tissues including lung, which provided strong evidence about relationship between SP-B and fibrosis [65-67]. Taken together, these findings indicate that SP-B is involved in lung fibrosis as a post-radiotherapy side effect in overall lung cancer patients. Indeed, the importance of SP-B treatment in alleviation of RDS has been demonstrated by many studies [68-70]. Unfortunately, the precise 3D structure and mechanism of surfactant function of SP-B had not been discovered [71]. Therefore, unveiling a biological method for functional treatment of alveoli with SP-B might be promising for further study.

Maturation into $9 \mathrm{kDa}$ of SP-B is processed through peptide cleavage of pro-SP-B (43 $\mathrm{kDa}$ ). Napsin $\mathrm{A}$, cathepsin $\mathrm{H}$, and pepsinogen $\mathrm{C}$ are known to be involved in maturation of SP-B. Napsin A cleaved the peptide bond between residues 178-179 and cathepsin H cleaved the peptide bond between residues 279-280 of pro-SP-B [46]. Pepsinogen C was reported to be solely involved in cleavage of peptide bonds between residues 196-197 and 302-303 [72]. Unexpectedly, several microarray analysis studies indicated that the expression of napsin A, cathepsin $\mathrm{H}$, and pepsinogen $\mathrm{C}$ in NSCLC were all lower than in normal lung tissue [35, $73,74]$. Moreover, silencing of each protease significantly reduced maturation of SP-B and subsequently reduced secretion of SP-B $[46,72]$. These studies indicated that the tumor suppressive role of SP-B was interrupted in lung cancer cells through post-translational modifications.

Although many studies have attempted to unveil the mechanism of radioresistance and malignant transformation in NSCLC that occurs after radiotherapy, it has not been completely controlled. The present study firstly suggests radiation-induced suppression of SP-B expression in which the radiation-induced TGF- $\beta$ signaling pathway and decreased SP-B enhanced growth and EMT of surviving NSCLC cells. Moreover, we found that a tumor-suppressive role of mature SP-B reduced SPLA2 activity and downstream MAPKs signaling transduction. We suggest that low SFTPB expression could be the driving force inducing malignancy of NSCLC and that ectopic administration of mature SP-B could be the radiosensitizing strategy for maximizing the efficacy of radiotherapy. 


\section{Cellular Physiology Cell Physiol Biochem 2017;42:1684-1700 \begin{tabular}{l|l|l} 
DOI: 10.1159/000479418 & $\begin{array}{l}\text { O 2017 The Author(s). Published by S. Karger AG, Basel } \\
\text { www.karger.com/cpb }\end{array}$ \\
\hline
\end{tabular}}

Lee et al.: SP-B Suppresses Progression of NSCLC

\section{Acknowledgements}

This work was supported by Radiation Technology R\&D program through the National Research Foundation of Korea funded by the Ministry of Science, ICT \& Future Planning (2017M2A2A7A01019304 to B Youn).

\section{Disclosure Statement}

The authors have no conflicts of interest to disclose.

\section{References}

1 Koh PK, Faivre-Finn C, Blackhall FH, De Ruysscher D: Targeted agents in non-small cell lung cancer (NSCLC): clinical developments and rationale for the combination with thoracic radiotherapy. Cancer Treat Rev 2012;38:626-640.

-2 Bussink J, van der Kogel AJ, Kaanders JH: Activation of the PI3-K/AKT pathway and implications for radioresistance mechanisms in head and neck cancer. Lancet Oncol 2008;9:288-296.

- 3 Yang HJ, Youn H, Seong KM, Jin YW, Kim J, Youn B: Phosphorylation of ribosomal protein S3 and antiapoptotic TRAF2 protein mediates radioresistance in non-small cell lung cancer cells. J Biol Chem 2013;288:2965-2975.

4 Kim W, Youn H, Seong KM, Yang HJ, Yun YJ, Kwon T, Kim YH, Lee JY, Jin YW, Youn B: PIM1-activated PRAS40 regulates radioresistance in non-small cell lung cancer cells through interplay with FOXO3a, 14-3-3 and protein phosphatases. Radiat Res 2011;176:539-552.

-5 Kim W, Youn H, Kwon T, Kang J, Kim E, Son B, Yang HJ, Jung Y, Youn B: PIM1 kinase inhibitors induce radiosensitization in non-small cell lung cancer cells. Pharmacol Res 2013;70:90-101.

-6 Kwon T, Youn H, Son B, Kim D, Seong KM, Park S, Kim W, Youn B: DANGER is involved in high glucoseinduced radioresistance through inhibiting DAPK-mediated anoikis in non-small cell lung cancer. Oncotarget 2016;7:7193-7206.

7 Whitsett JA, Weaver TE: Hydrophobic surfactant proteins in lung function and disease. N Engl J Med 2002;347:2141-2148.

8 Wustneck R, Perez-Gil J, Wustneck N, Cruz A, Fainerman VB, Pison U: Interfacial properties of pulmonary surfactant layers. Adv Colloid Interface Sci 2005;117:33-58.

-9 Han S, Mallampalli RK: The Role of Surfactant in Lung Disease and Host Defense against Pulmonary Infections. Ann Am Thorac Soc 2015;12:765-774.

10 Schurch D, Ospina OL, Cruz A, Perez-Gil J: Combined and independent action of proteins SP-B and SP-C in the surface behavior and mechanical stability of pulmonary surfactant films. Biophys J 2010;99:32903299.

11 Rodriguez-Capote K, Nag K, Schurch S, Possmayer F: Surfactant protein interactions with neutral and acidic phospholipid films. Am J Physiol Lung Cell Mol Physiol 2001;281:L231-242.

12 Taguchi A, Politi K, Pitteri SJ, Lockwood WW, Faca VM, Kelly-Spratt K, Wong CH, Zhang Q, Chin A, Park KS, Goodman G, Gazdar AF, Sage J, Dinulescu DM, Kucherlapati R, Depinho RA, Kemp CJ, Varmus HE, Hanash SM: Lung cancer signatures in plasma based on proteome profiling of mouse tumor models. Cancer Cell 2011;20:289-299.

13 Sin DD, Tammemagi CM, Lam S, Barnett MJ, Duan X, Tam A, Auman H, Feng Z, Goodman GE, Hanash S, Taguchi A: Pro-surfactant protein B as a biomarker for lung cancer prediction. J Clin Oncol 2013;31:45364543.

14 Wang M, Hao FY, Wang JG, Xiao W: Group IIa secretory phospholipase A2 (sPLA2IIa) and progression in patients with lung cancer. Eur Rev Med Pharmacol Sci 2014;18:2648-2654.

-15 Yu JA, Kalatardi S, Dohse J, Sadaria MR, Meng X, Fullerton DA, Weyant MJ: Group IIa sPLA2 inhibition attenuates NF-kappaB activity and promotes apoptosis of lung cancer cells. Anticancer Res 2012;32:36013607. 


\section{Cellular Physiology Cell Physiol Biochem 2017;42:1684-1700 \begin{tabular}{l|l} 
DOI: 10.1159/000479418 & $\begin{array}{l}\text { O 2017 The Author(s). Published by S. Karger AG, Basel } \\
\text { www.karger.com/cpb }\end{array}$ \\
\hline
\end{tabular}}

Lee et al.: SP-B Suppresses Progression of NSCLC

16 Quach ND, Arnold RD, Cummings BS: Secretory phospholipase A2 enzymes as pharmacological targets for treatment of disease. Biochem Pharmacol 2014;90:338-348.

17 Nishizuka Y: Intracellular signaling by hydrolysis of phospholipids and activation of protein kinase C. Science 1992;258:607-614.

18 Han WK, Sapirstein A, Hung CC, Alessandrini A, Bonventre JV: Cross-talk between cytosolic phospholipase A2 alpha (cPLA2 alpha) and secretory phospholipase A2 (sPLA2) in hydrogen peroxide-induced arachidonic acid release in murine mesangial cells: sPLA2 regulates CPLA2 alpha activity that is responsible for arachidonic acid release. J Biol Chem 2003;278:24153-24163.

19 Rupprecht G, Scholz K, Beck KF, Geiger H, Pfeilschifter J, Kaszkin M: Cross-talk between group IIAphospholipase A(2) and inducible NO-synthase in rat renal mesangial cells. Br J Pharmacol 1999;127:5156.

20 Sakai M, Kakutani S, Horikawa C, Tokuda H, Kawashima H, Shibata H, Okubo H, Sasaki S: Arachidonic acid and cancer risk: a systematic review of observational studies. BMC Cancer 2012;12:606.

21 Greenhough A, Smartt HJM, Moore AE, Roberts HR, Williams AC, Paraskeva C, Kaidi A: The COX-2/ PGE2 pathway: key roles in the hallmarks of cancer and adaptation to the tumour microenvironment. Carcinogenesis 2009;30:377-386.

22 Vitale P, Panella A, Scilimati A, Perrone MG: COX-1 Inhibitors: Beyond Structure Toward Therapy. Med Res Rev 2016;36:641-671.

23 Hite RD, Grier BL, Waite BM, Veldhuizen RA, Possmayer F, Yao LJ, Seeds MC: Surfactant protein B inhibits secretory phospholipase A2 hydrolysis of surfactant phospholipids. Am J Physiol Lung Cell Mol Physiol 2012;302:L257-265.

-24 Kang J, Kim W, Kwon T, Youn H, Kim JS, Youn B: Plasminogen activator inhibitor-1 enhances radioresistance and aggressiveness of non-small cell lung cancer cells. Oncotarget 2016;7:23961-23974.

-25 Youn H, Son B, Kim W, Jun SY, Lee JS, Lee JM, Kang C, Kim J, Youn B: Dissociation of MIF-rpS3 complex and sequential NF-kappaB activation is involved in IR-induced metastatic conversion of NSCLC. J Cell Biochem 2015;116:2504-2516.

26 Kim W, Yang HJ, Youn H, Yun YJ, Seong KM, Youn B: Myricetin inhibits Akt survival signaling and induces Bad-mediated apoptosis in a low dose ultraviolet (UV)-B-irradiated HaCaT human immortalized keratinocytes. J Radiat Res 2010;51:285-296.

27 Kang J, Kim E, Kim W, Seong KM, Youn H, Kim JW, Kim J, Youn B: Rhamnetin and cirsiliol induce radiosensitization and inhibition of epithelial-mesenchymal transition (EMT) by miR-34a-mediated suppression of Notch-1 expression in non-small cell lung cancer cell lines. J Biol Chem 2013;288:2734327357.

28 Son B, Jun SY, Seo H, Youn H, Yang HJ, Kim W, Kim HK, Kang C, Youn B: Inhibitory effect of traditional oriental medicine-derived monoamine oxidase B inhibitor on radioresistance of non-small cell lung cancer. Sci Rep 2016;6:21986.

29 Kim W, Youn H, Kang C, Youn B: Inflammation-induced radioresistance is mediated by ROS-dependent inactivation of protein phosphatase 1 in non-small cell lung cancer cells. Apoptosis 2015;20:1242-1252.

- 30 Kang J, Kim W, Lee S, Kwon D, Chun J, Son B, Kim E, Lee JM, Youn H, Youn B: TFAP2C promotes lung tumorigenesis and aggressiveness through miR-183- and miR-33a-mediated cell cycle regulation. Oncogene 2017;36:1585-1596.

-31 Kim W, Kim E, Lee S, Kim D, Chun J, Park KH, Youn H, Youn B: TFAP2C-mediated upregulation of TGFBR1 promotes lung tumorigenesis and epithelial-mesenchymal transition. Exp Mol Med 2016;48:e273.

32 Kim W, Kim E, Yang HJ, Kwon T, Han S, Lee S, Youn H, Jung Y, Kang C, Youn B: Inhibition of hedgehog signalling attenuates UVB-induced skin photoageing. Exp Dermatol 2015;24:611-617.

33 Euhus DM, Hudd C, LaRegina MC, Johnson FE: Tumor measurement in the nude mouse. J Surg Oncol 1986;31:229-234.

-34 Landi MT, Dracheva T, Rotunno M, Figueroa JD, Liu H, Dasgupta A, Mann FE, Fukuoka J, Hames M, Bergen AW, Murphy SE, Yang P, Pesatori AC, Consonni D, Bertazzi PA, Wacholder S, Shih JH, Caporaso NE, Jen J: Gene expression signature of cigarette smoking and its role in lung adenocarcinoma development and survival. PLoS One 2008;3:e1651.

-35 Garber ME, Troyanskaya OG, Schluens K, Petersen S, Thaesler Z, Pacyna-Gengelbach M, van de Rijn M, Rosen GD, Perou CM, Whyte RI, Altman RB, Brown PO, Botstein D, Petersen I: Diversity of gene expression in adenocarcinoma of the lung. Proc Natl Acad Sci U S A 2001;98:13784-13789. 


\section{Cellular Physiology Cell Physiol Biochem 2017;42:1684-1700 \begin{tabular}{l|l} 
DOI: 10.1159/000479418 & $\begin{array}{l}\text { O 2017 The Author(s). Published by S. Karger AG, Basel } \\
\text { www.karger.com/cpb }\end{array}$ \\
\hline
\end{tabular}}

-36 Khoor A, Whitsett JA, Stahlman MT, Olson SJ, Cagle PT: Utility of surfactant protein B precursor and thyroid transcription factor 1 in differentiating adenocarcinoma of the lung from malignant mesothelioma. Human Pathology 1999;30:695-700.

- 37 Kim E, Youn H, Kwon T, Son B, Kang J, Yang HJ, Seong KM, Kim W, Youn B: PAK1 tyrosine phosphorylation is required to induce epithelial-mesenchymal transition and radioresistance in lung cancer cells. Cancer Res 2014;74:5520-5531.

-38 Debnath J, Brugge JS: Modelling glandular epithelial cancers in three-dimensional cultures. Nat Rev Cancer 2005;5:675-688.

- 39 Li X, Ishihara S, Yasuda M, Nishioka T, Mizutani T, Ishikawa M, Kawabata K, Shirato H, Haga H: Lung cancer cells that survive ionizing radiation show increased integrin alpha2beta1- and EGFR-dependent invasiveness. PLoS One 2013;8:e70905.

40 Calaf GM, Roy D, Narayan G, Balajee AS: Differential expression of cell adhesion molecules in an ionizing radiation-induced breast cancer model system. Oncol Rep 2013;30:285-291.

-41 Rucka Z, Vanhara P, Koutna I, Tesarova L, Potesilova M, Stejskal S, Simara P, Dolezel J, Zvonicek V, Coufal O, Capov I: Differential effects of insulin and dexamethasone on pulmonary surfactant-associated genes and proteins in A549 and H441 cells and lung tissue. Int J Mol Med 2013;32:211-218.

42 Buhling F, Kouadio M, Chwieralski CE, Kern U, Hohlfeld JM, Klemm N, Friedrichs N, Roth W, Deussing JM, Peters C, Reinheckel T: Gene targeting of the cysteine peptidase cathepsin H impairs lung surfactant in mice. PLoS One 2011;6:e26247.

43 Citrin DE, Shankavaram U, Horton JA, Shield W, 3rd, Zhao S, Asano H, White A, Sowers A, Thetford A, Chung EJ: Role of type II pneumocyte senescence in radiation-induced lung fibrosis. J Natl Cancer Inst 2013;105:1474-1484.

44 Minoo P, Hu L, Zhu N, Borok Z, Bellusci S, Groffen J, Kardassis D, Li C: SMAD3 prevents binding of NKX2.1 and FOXA1 to the SpB promoter through its MH1 and MH2 domains. Nucleic Acids Res 2008;36:179-188.

-45 Jiang Y, Chen X, Tian W, Yin X, Wang J, Yang H: The role of TGF-beta1-miR-21-R0S pathway in bystander responses induced by irradiated non-small-cell lung cancer cells. Br J Cancer 2014;111:772-780.

46 Ueno T, Linder S, Na CL, Rice WR, Johansson J, Weaver TE: Processing of pulmonary surfactant protein B by napsin and cathepsin H. J Biol Chem 2004;279:16178-16184.

47 Leslie CC: Cytosolic phospholipase A(2): physiological function and role in disease. J Lipid Res 2015;56:1386-1402.

48 Martinez-Orozco R, Navarro-Tito N, Soto-Guzman A, Castro-Sanchez L, Perez Salazar E: Arachidonic acid promotes epithelial-to-mesenchymal-like transition in mammary epithelial cells MCF10A. Eur J Cell Biol 2010;89:476-488.

49 Tabriz HM, Mirzaalizadeh M, Gooran S, Niki F, Jabri M: COX-2 Expression in Renal Cell Carcinoma and Correlations with Tumor Grade, Stage and Patient Prognosis. Asian Pac J Cancer Prev 2016;17:535-538.

50 Gyorffy B, Surowiak P, Budczies J, Lanczky A: Online survival analysis software to assess the prognostic value of biomarkers using transcriptomic data in non-small-cell lung cancer. PLoS One 2013;8:e82241.

-51 Gronberg BH, Lund-Iversen M, Strom EH, Brustugun OT, Scott H: Associations between TS, TTF-1, FR-alpha, FPGS, and overall survival in patients with advanced non-small-cell lung cancer receiving pemetrexed plus carboplatin or gemcitabine plus carboplatin as first-line chemotherapy. J Thorac Oncol 2013;8:1255-1264.

-52 Chua CE, Chan SN, Tang BL: Non-cell autonomous or secretory tumor suppression. J Cell Physiol 2014;229:1346-1352.

53 Gupta P, Emdad L, Lebedeva IV, Sarkar D, Dent P, Curiel DT, Settleman J, Fisher PB: Targeted combinatorial therapy of non-small cell lung carcinoma using a GST-fusion protein of full-length or truncated MDA-7/IL24 with Tarceva. J Cell Physiol 2008;215:827-836.

54 Fisher PB, Gopalkrishnan RV, Chada S, Ramesh R, Grimm EA, Rosenfeld MR, Curiel DT, Dent P: mda-7/IL24 , a novel cancer selective apoptosis inducing cytokine gene: from the laboratory into the clinic. Cancer Biol Ther 2003;2:S23-37.

-55 Cunningham CC, Chada S, Merritt JA, Tong A, Senzer N, Zhang Y, Mhashilkar A, Parker K, Vukelja S, Richards D, Hood J, Coffee K, Nemunaitis J: Clinical and local biological effects of an intratumoral injection of mda-7 (IL24; INGN 241) in patients with advanced carcinoma: a phase I study. Mol Ther 2005;11:149-159. 


\section{Cellular Physiology Cell Physiol Biochem 2017;42:1684-1700 \begin{tabular}{l|l} 
DOI: 10.1159/000479418 & $\begin{array}{l}\text { O 2017 The Author(s). Published by S. Karger AG, Basel } \\
\text { www.karger.com/cpb }\end{array}$ \\
\hline
\end{tabular}}

Lee et al.: SP-B Suppresses Progression of NSCLC

-56 Chan QK, Ngan HY, Ip PP, Liu VW, Xue WC, Cheung AN: Tumor suppressor effect of follistatin-like 1 in ovarian and endometrial carcinogenesis: a differential expression and functional analysis. Carcinogenesis 2009;30:114-121.

57 Zhang D, Ma X, Sun W, Cui P, Lu Z: Down-regulated FSTL5 promotes cell proliferation and survival by affecting Wnt/beta-catenin signaling in hepatocellular carcinoma. Int J Clin Exp Pathol 2015;8:3386-3394.

\58 Hasegawa Y, Takahashi M, Ariki S, Asakawa D, Tajiri M, Wada Y, Yamaguchi Y, Nishitani C, Takamiya R, Saito A, Uehara Y, Hashimoto J, Kurimura Y, Takahashi H, Kuroki Y: Surfactant protein D suppresses lung cancer progression by downregulation of epidermal growth factor signaling. Oncogene 2015;34:838-845.

-59 Madani I, De Ruyck K, Goeminne H, De Neve W, Thierens H, Van Meerbeeck J: Predicting risk of radiationinduced lung injury. J Thorac Oncol 2007;2:864-874.

-60 Cabrera-Benitez NE, Laffey JG, Parotto M, Spieth PM, Villar J, Zhang H, Slutsky AS: Mechanical ventilationassociated lung fibrosis in acute respiratory distress syndrome: a significant contributor to poor outcome. Anesthesiology 2014;121:189-198.

61 Silva JD, de Oliveira GP, Samary Cdos S, Araujo CC, Padilha Gde A, Costa e Silva Filho F, da Silva RT, EinickerLamas M, Morales MM, Capelozzi VL, da Silva VM, Lima LM, Barreiro EJ, Diaz BL, Pelosi P, Silva PL, Garcia CS, Rocco PR: Respiratory and Systemic Effects of LASSBio596 Plus Surfactant in Experimental Acute Respiratory Distress Syndrome. Cell Physiol Biochem 2016;38:821-835.

62 Wert SE, Whitsett JA, Nogee LM: Genetic disorders of surfactant dysfunction. Pediatr Dev Pathol 2009;12:253-274.

63 Melton KR, Nesslein LL, Ikegami M, Tichelaar JW, Clark JC, Whitsett JA, Weaver TE: SP-B deficiency causes respiratory failure in adult mice. Am J Physiol Lung Cell Mol Physiol 2003;285:L543-549.

64 Takahashi H, Imai Y, Fujishima T, Shiratori M, Murakami S, Chiba H, Kon H, Kuroki Y, Abe S: Diagnostic significance of surfactant proteins A and D in sera from patients with radiation pneumonitis. Eur Respir J 2001;17:481-487.

-65 Wang L, Wang Y, Yang T, Guo Y, Sun T: Angiotensin-Converting Enzyme 2 Attenuates Bleomycin-Induced Lung Fibrosis in Mice. Cell Physiol Biochem 2015;36:697-711.

66 Sommerfeld A, Reinehr R, Haussinger D: Tauroursodeoxycholate Protects Rat Hepatocytes from Bile AcidInduced Apoptosis via beta1-Integrin- and Protein Kinase A-Dependent Mechanisms. Cell Physiol Biochem 2015;36:866-883.

67 Ding W, Wang B, Zhang M, Gu Y: Involvement of Endoplasmic Reticulum Stress in Uremic Cardiomyopathy: Protective Effects of Tauroursodeoxycholic Acid. Cell Physiol Biochem 2016;38:141-152.

68 Olmeda B, Garcia-Alvarez B, Perez-Gil J: Structure-function correlations of pulmonary surfactant protein SP-B and the saposin-like family of proteins. Eur Biophys J 2013;42:209-222.

69 Curstedt T, Johansson J: Different effects of surfactant proteins B and C - implications for development of synthetic surfactants. Neonatology 2010;97:367-372.

-70 Sardesai S, Biniwale M, Wertheimer F, Garingo A, Ramanathan R: Evolution of surfactant therapy for respiratory distress syndrome: past, present, and future. Pediatr Res 2017;81:240-248.

-71 Banfi C, Agostoni P: Surfactant protein B: From biochemistry to its potential role as diagnostic and prognostic marker in heart failure. Int J Cardiol 2016;221:456-462.

-72 Gerson KD, Foster CD, Zhang P, Zhang Z, Rosenblatt MM, Guttentag SH: Pepsinogen C proteolytic processing of surfactant protein B. J Biol Chem 2008;283:10330-10338.

73 Bhattacharjee A, Richards WG, Staunton J, Li C, Monti S, Vasa P, Ladd C, Beheshti J, Bueno R, Gillette M, Loda M, Weber G, Mark EJ, Lander ES, Wong W, Johnson BE, Golub TR, Sugarbaker DJ, Meyerson M: Classification of human lung carcinomas by mRNA expression profiling reveals distinct adenocarcinoma subclasses. Proc Natl Acad Sci U S A 2001;98:13790-13795.

-74 Hou J, Aerts J, den Hamer B, van Ijcken W, den Bakker M, Riegman P, van der Leest C, van der Spek P, Foekens JA, Hoogsteden HC, Grosveld F, Philipsen S: Gene expression-based classification of non-small cell lung carcinomas and survival prediction. PLoS One 2010;5:e10312. 